\title{
Sosialisasi Perkembangan Pengetahuan dan Pemeriksaan Covid-19 di Universitas Mohammad Husni Thamrin
}

\author{
"Prima Nanda Fauziah ${ }^{1)}$, Lenggo Geni ${ }^{2)}$, Mahmudah ${ }^{3)}$, Zuraida $^{4)}$
}

Program Studi Analis Kesehatan, Fakultas Kesehatan, Universitas Mohammad Husni Thamrin

Correspondence author: primanandafauziah@gmail.com

Received : 20 Agustus $2021 \quad$ Accepted : 29 September 2021

Published: 30 September 2021

DOI: https://doi.org/10.37012/jpkmht.v3i2.702

\begin{abstract}
ABSTRAK
Saat ini, dunia sedang dilanda pandemi yang cukup membahayakan, yaitu Coronavirus Disease 2019 (Covid19). Pemerintah Indonesia telah menetapkan status darurat bencana terkait dengan pandemi virus ini. Salah satu langkah efektif untuk memutuskan rantai penularan dilakukan dengan menerapkan protokol kesehatan secara disiplin. Namun demikian, masih banyak masyarakat yang tidak mengikuti protokol tersebut. Sebagai upaya pencegahan dini, maka dilakukannya kegiatan pengabdian kepada masyarakat (PkM) yang merupakan suatu bentuk pendidikan dengan cara memberikan pengalaman belajar kepada dosen dan mahasiswa untuk dapat mengidentifikasi serta menangani masalah-masalah kesehatan yang dihadapi di masyarakat. Kegiatan PkM kali ini berupa sosialisasi secara daring dalam bentuk webinar dengan judul "Peningkatan Pengetahuan Covid-19 pada Mahasiswa" dengan peserta adalah mahasiswa jurusan Analis Kesehatan, Universitas Mohammad Husni Thamrin, Jakarta. Webinar yang dilakukan terdiri dari paparan materi terkait perkembangan Covid-19 dan juga teknik pemeriksaan laboratorium Covid-19 sebagai wawasan tambahan, serta adanya pre-test dan post test. Hasil kuisioner menunjukkan peserta dari Universitas Mohammad Husni Thamrin ini dalam keadaan sehat, namun untuk tingkat kesadaran terhadap kesehatan masih kurang yang ditandai dengan pola hidup yang kurang sehat, jarang berolahraga dan jarangnya memeriksaan diri kepelayanan kesehatan. Terlihat adanya kenaikan nilai antara nilai pre-test dengan nilai post-test setelah dilakukan sosialisasi. Hasil kegiatan sosialisasi ini diharapkan dapat memotivasi mahasiswa untuk lebih meningkatkan promosi kesehatan maupun pengetahuan mengenai Covid-19
\end{abstract}

Kata Kunci: Covid-19, PkM, Sosialisasi, Webinar.

\begin{abstract}
Coronavirus Disease 2019 (COVID-19) pandemi has been going on for quite a while worldwide. Indonesia government has established the pandemi as emergency disaster. The transmission has been continously prevented through rigid protocol. However, the obedience of people to follow the protocol strictly remains challenging. Pengabdian kepada Masyarakatt (PkM) is an educational program involving lecturer to investigate as well as to solve the ongoing health issues in society. This year, the activity was carried out in an online seminar (webinar) entitled "Peningkatan Pengetahuan Covid-19 pada Mahasiswa" which was aimed to students of Health Analyst in Universitas Mohammad Husni Thamrin Jakarta. This event provides updated information in regards of Covid-19 diagnostic tests which is appropriate and valuable to the students. Furthermore, evaluation of knowledges of participants were also done based on quistionnaire. The results showed that students were healthy, however, sort of ignored the Covid-19 protocol on daily basis. After webinar, there was an escalation in knowledges of participant as shown in higher grade of post-test compared to pre test. Overall, the webinar went well and hopefully encourage both teachers and students to be more dicipline in implementing Covid-19 protocol.
\end{abstract}

Keywords: Covid-19, PkM, Sosialisation, Webinar. 


\section{PENDAHULUAN}

Saat ini dunia sedang dilanda pandemi yang cukup meresahkan, yaitu Coronavirus Disease 2019 atau yang biasa disebut Covid-19. Covid-19 merupakan penyakit menular yang disebabkan oleh severe acute respiratory syndrome coronavirus 2 (SARS-CoV-2) (Setiati dan Azwar, 2020). Indonesia telah menetapkan status darurat bencana terkait dengan pandemi ini. Pemutusan rantai penularan bisa dilaksanakan dengan menerapkan protokol kesehatan secara tegas dan disiplin, yaitu dengan cara sering mencuci tangan dengan air mengalir dan sabun atau menggunakan hand sanitizer, menggunakan masker dan tidak menyentuh area muka sebelum mencuci tangan, serta menjaga jarak dalam setiap berkegiatan atau yang dikenal dengan istilah 3M (Adhikari dan Meng, 2020). Tak hanya itu, pemerintah juga telah membuat kebijakan untuk menerapkan physical distancing untuk memutuskan penyebaran Covid-19. Masyarakat dihimbau untuk tidak melakukan kontak langsung dengan orang lain, menghindari pertemuan yang bersifat massal. Aktivitas bekerja, belajar dan beribadah dilaksanakan dari rumah sementara waktu (Adhikari dan Meng, 2020; Kementerian Kesehatan RI, 2020).

Akan tetapi, masih banyak masyarakat yang tidak mengikuti anjuran tersebut. Siswa dan mahasiswa yang proses belajar mengajar dilakukan dari rumah memanfaatkan waktu itu untuk berlibur, berekreasi ke mall, bioskop, atau kepuncak. Remaja dan orang muda harus meningkatkan kesiapsiagaan terhadap penyakit ini (Natalia dkk., 2020). Remaja merupakan bagian dari masyarakat yang tidak dapat sepelekan dalam upaya pencegahan penularan penyakit ini. Penerapan protokol kesehatan guna pemutusan mata rantai penyebaran Covid-19 terutama pada remaja memerlukan pemahaman dan pengetahuan yang baik.

Sehubungan dengan latar belakang tersebut, maka dilakukan kegiatan Pengabdian kepada Masyarakat $(\mathrm{PkM})$ yang merupakan suatu bentuk pendidikan dengan cara memberikan pengalaman promosi kesehatan kepada mahasiswa cara untuk dapat mengidentifikasi serta menangani masalah-masalah kesehatan yang dihadapi di masyarakat. Di tengah pandemi ini, PkM dilakukan secara daring melalui pelaksanaan Webinar dan diharapkan dapat meningkatkan pengetahuan mahasiswa Universitas Mohammad Husni Thamrin tentang Covid-19 serta pencegahannya guna memutus mata rantai penyebaran Covid-19.

\section{METODE}

Sasaran kegiatan PkM adalah mahasiswa Program Studi Analis Kesehatan Universitas Mohammad Husni Thamrin. 
Webinar mengambil judul "Peningkatan Pengetahuan Covid-19 pada Mahasiswa" dan dilaksanakan pada tanggal 10 Oktober 2020 yang dimulai pukul 09.00 WIB melalui aplikasi zoom meeting. Adapun panitia pada kegiatan PkM ini meliputi Prima Nanda Fauziah, S.Si,m M.Si., Lenggo Geni S.Pd., M.Biomed., Mahmudah, S.Si., M.Biomed., dan Zuraida, SKM., MKM. Peserta webinar diminta mengisi kuisioner berupa data kesehatan diri, serta pre- dan post-test mengenai materi Covid-19 melalui Google Form, kemudian data direkap oleh panitia.

\section{HASIL DAN PEMBAHASAN}

Kegiatan PkM dilakukan dalam bentuk webinar, yang diinfokan melalui poster (Gambar 1). Sasaran yang dipilih adalah mahasiswa Universitas Mohammad Husni Thamrin yang merupakan salah satu kampus kesehatan yang terletak di daerah Pondok Gede, Kota Jakarta Timur, Provinsi DKI Jakarta. Universitas Mohammad Husni Thamrin memiliki sekitar 800 lebih mahasiswa. Pada kegiatan PkM ini, sosialisasi Covid-19 dilakukan hanya pada mahasiswa Program Studi Analis Kesehatan. Peserta yang menghadiri sosialisasi berjumlah 385 orang dari 423 orang yang mendaftar (Gambar 2). Tidak semua mahasiswa mengikuti kegiatan sosialisasi karena kendala sinyal di tempat tinggal mereka sehingga mereka mengalami kesulitan untuk masuk ke dalam Zoom meeting.

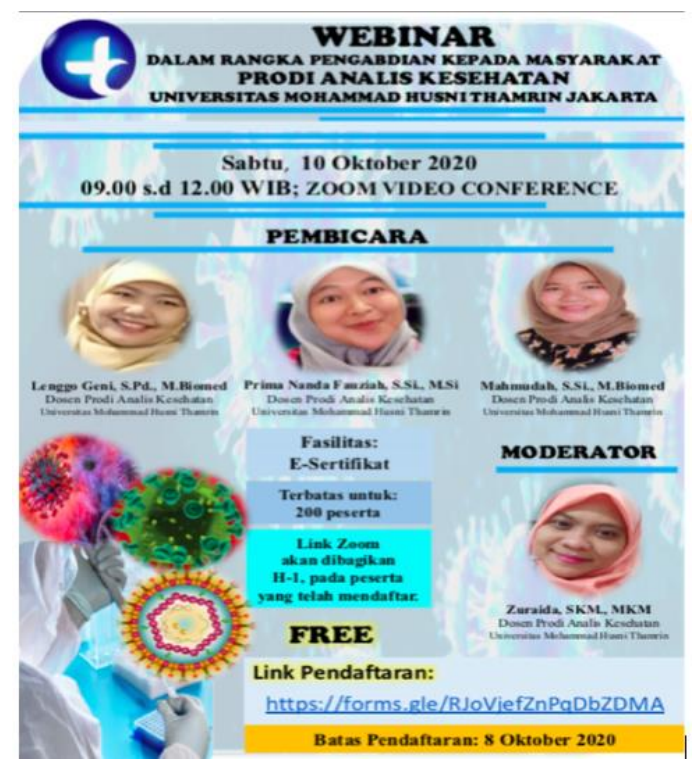

Gambar 1. Poster Webinar Sosialisasi Pencegahan Covid-19 


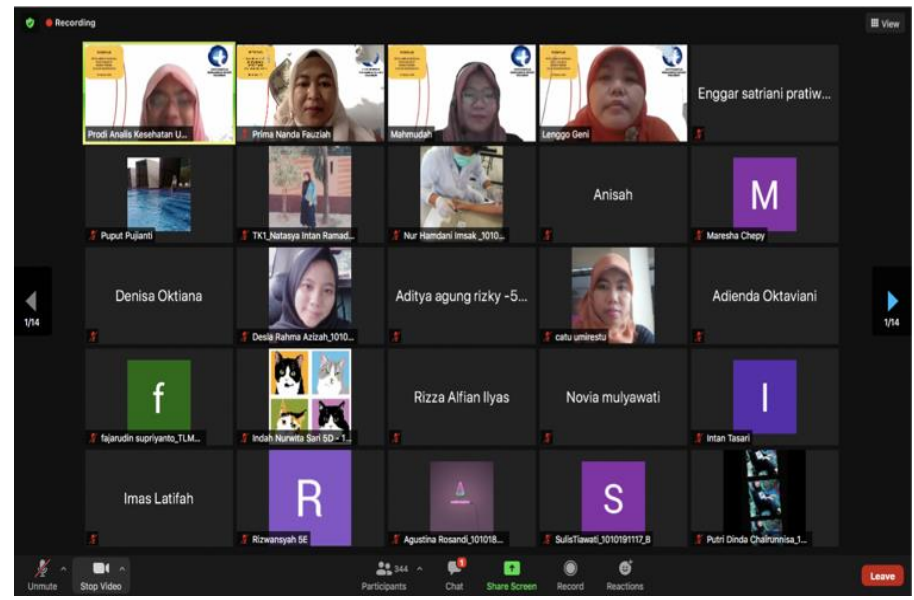

Gambar 2. Peserta Webinar Sosialisasi Pencegahan Covid-19 di Universitas Mohammad Husni Thamrin

Narasumber yang merupakan dosen mata kuliah virologi memberi paparan kepada peserta dalam bentuk slide presentasi dan video dokumentasi tentang pemeriksaan swab untuk dapat membantu meningkatkan pemahaman bagi peserta mengenai materi yang dibahas (Gambar 3). Materi paparan terdiri dari karakteristik virus SARS-CoV-2, penularan Covid-19, upaya pencegahan, dan perkembangan vaksin beserta mekanisme kerjanya. Selain itu, peserta juga dikenalkan dengan jenis-jenis pemeriksaan Covid-19 terutama pemeriksaan yang berbasis molekuler. Sehubungan dengan peserta yang merupakan mahasiswa Program Studi Analis Kesehatan, pengenalan terhadap teknik pemeriksaan Covid-19 dirasa sangat penting untuk menambah wawasan dan mempersiapkan mereka sebelum terjun ke dunia kerja.

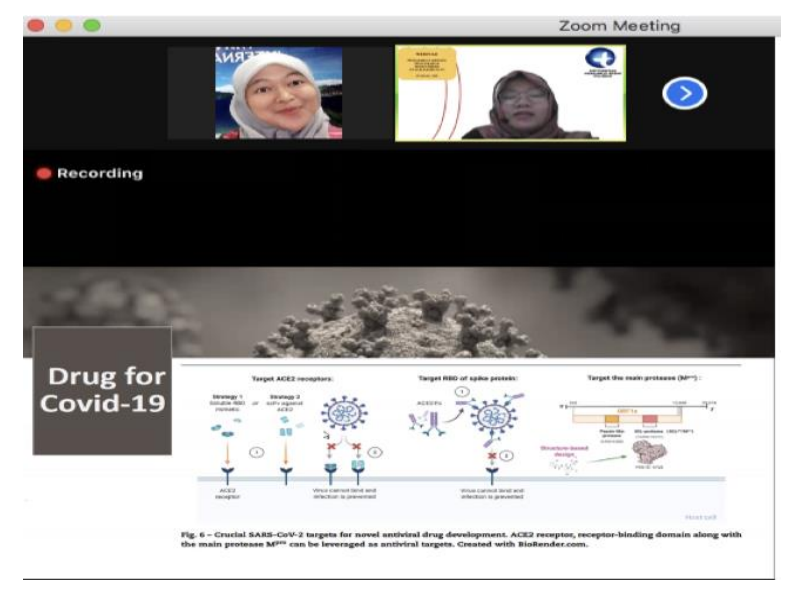

Gambar 3. Pemaparan Materi Sosialisasi Pencegahan Covid-19 di Universitas Mohammad Husni Thamrin

Evaluasi kegiatan dilakukan dalam bentuk kuisioner. Terdapat dua kuisioner, yaitu kuisioner data kesehatan peserta dan kuisioner tentang pemahaman peserta. Berdasarkan hasil kuisioner data kesehatan (Tabel 1 ), sebagian mahasiswa Program Studi Analis Kesehatan 
Universitas Mohammad Husni Thamrin dalam keadaan sehat, namun tingkat kesadaran terhadap kesehatan masih kurang yang ditandai dengan pola hidup kurang sehat. Selain itu, tingkat kesadaran terhadap bahaya Covid-19 ini pun juga masih kurang. Hal ini dapat dilihat dari masih seringnya mereka berkumpul di tempat ramai, tidak menjaga jarak, tidak menggunakan pelindung wajah yang efektif, jarang mengganti pakaian setelah berpergian atau mandi setelah melakukan aktivitas di luar, dan tidak melakukan pemeriksaan dini terhadap penyakit Covid-19. Meskipun demikian, para mahasiswa sudah melakukan kegiatan yang membantu dalam memberantas penyebaran penyakit Covid-19 antara lain dengan pemakaian masker walaupun masih ada yang menggunakan masker kain yang keefektifannya masih kurang, tidak berpegian keluar daerah, tidak menggunakan kendaraan umum yang kemungkinan terpapar, dan sering melakukan cuci tangan.

Tabel 1. Hasil kuisioner data kesehatan mahasiswa Program Studi Analis Universitas Mohammad Husni Thamrin

\begin{tabular}{|c|c|c|c|c|c|}
\hline No. & Variabel & $\begin{array}{c}\text { Jumlah } \\
(\%)\end{array}$ & No. & Variabel & $\begin{array}{c}\text { Jumlah } \\
(\%)\end{array}$ \\
\hline 1 & Riwayat penyakit & & 7 & $\begin{array}{l}\text { Mengalami gejala Covid-19 } \\
\text { dalam waktu } 14 \text { hari terakhir }\end{array}$ & \\
\hline & Maag & $10 \%$ & & Ya & $0 \%$ \\
\hline & Asam Lambung & $10 \%$ & & Tidak & $100 \%$ \\
\hline & Radang Usus & $5 \%$ & 8 & Berada di tempat berkerumun & \\
\hline & Tipoid & $5 \%$ & & Ya & $15 \%$ \\
\hline & Asma & $5 \%$ & & Tidak & $85 \%$ \\
\hline & Tidak ada & $65 \%$ & 9 & $\begin{array}{l}\text { Kontak langsung dengan } \\
\text { penderita Covid-19 }\end{array}$ & \\
\hline 2 & Keadaan saat ini & & & $\mathrm{Ya}$ & $0 \%$ \\
\hline & Sakit & $15 \%$ & & Tidak & $100 \%$ \\
\hline & Tidak sakit & $85 \%$ & 10 & $\begin{array}{l}\text { Keluarga/kerabat terkena } \\
\text { Covid-19 }\end{array}$ & \\
\hline 3 & Penanganan ketika sakit & & & $\mathrm{Ya}$ & $0 \%$ \\
\hline & $\begin{array}{l}\text { Berobat ke pelayanan } \\
\text { kesehatan }\end{array}$ & $80 \%$ & & Tidak & $100 \%$ \\
\hline & Konsumsi obat sendiri & $20 \%$ & 11 & Pernah melakukan Rapid Test & \\
\hline 4 & Berolahraga & & & Ya & $10 \%$ \\
\hline & $\mathrm{Ya}$ & $6 \%$ & & Tidak & $90 \%$ \\
\hline & Tidak & $13 \%$ & 12 & Hasil Rapid Test & \\
\hline & Kadang-kadang & $81 \%$ & & Reaktif & $0 \%$ \\
\hline 5 & $\begin{array}{l}\text { Berpergian ke luar Kota } \\
\text { dalam waktu } 14 \text { hari terakhir }\end{array}$ & & & Non Reaktif & $100 \%$ \\
\hline & Ya & $9 \%$ & 13 & Pernah melakukan Swab Test & \\
\hline & Tidak & $91 \%$ & & Ya & $10 \%$ \\
\hline 6 & $\begin{array}{l}\text { Mengalami demam diatas } \\
37^{\circ} \mathrm{C} \text { dalam waktu } 14 \text { hari } \\
\text { terakhir }\end{array}$ & & & Tidak & $90 \%$ \\
\hline & $\mathrm{Ya}$ & $0 \%$ & & & \\
\hline & Tidak & $100 \%$ & & & \\
\hline
\end{tabular}


Kuisioner pemahaman peserta dibagi menjadi dua, yaitu kuisioner pengetahuan awal (pretest) yang diberikan sebelum peserta mendapatkan materi, dan yang kedua adalah kuisioner pengetahuan akhir (post-test) yang diberikan setelah paparan materi. Berdasarkan hasil posttest, terlihat adanya perbedaan dengan hasil pre-test dimana terjadi kenaikan yang signifikan mencapai 90\%. Kenaikan ini menunjukan bahwa pengetahuan dari mahasiswa meningkat. Jumlah mahasiswa yang mengalami peningkatan lebih tinggi dibandingkan dengan yang mengalami penurunan atau yang tidak mengalami perubahan sama sekali.

Hasil kegiatan sosialisasi ini diharapkan dapat memotivasi para pengajar untuk lebih meningkatkan promosi kesehatan maupun pengetahuan mengenai Covid-19 agar mahasiswa senantiasa mengenal dan memahami dampak dan cara penanganan yang harus diterapkan. Selain itu, untuk kegiatan PkM selanjutnya dapat disertai juga dengan pemeriksaan laboratorium sehingga masalah-masalah kesehatan dalam masyarakat dapat terdeteksi.

\section{SIMPULAN}

Kegiatan webinar berlangsung dengan lancar, dan peserta yaitu mahasiswa Program Studi Analis Kesehatan Universitas Mohammad Husni Thamrin juga menunjukkan peningkatan dalam pengetahuan yang mencapai $90 \%$ terkait perkembangan dan teknik pemeriksaan Covid-19.

\section{REFERENSI}

1. Setiati, S., Azwar, M.K. (2020). Covid-19 and Indonesia. Acta Medica Indonesiana, 52(1)., 84-9.

2. Adhikari, S.P., Meng, S., Wu, Y.J. (2020). Epidemiology, causes, clinical manifestation and diagnosis, prevention and control of coronavirus disease (COVID19) during the early outbreak period: a scoping review. Infect Dis Poverty, 9(1):29.

3. Kementerian Kesehatan Republik Indonesia. (2020). Info Infeksi Emerging Kementerian Kesehatan RI. Kementerian Kesehatan Republik Indonesia. Jakarta.

4. Natalia, R. N., Malinti, E., \& Elon, Y. (2020). Kesiapsiagaan Remaja Dalam Menghadapi Wabah Covid-19. Jurnal Ilmiah Kesehatan Diagnosis, 15(2).

5. Anggreni, D., Safitri, C.A. (2020). Hubungan Pengetahuan Remaja Tentang Covid-19 Dengan kepatuhan Dalam menerapkan protokol Kesehatan Di Masa New Normal. Hospital Majapahit Vol 12 No. 2 November 2020. 12(2), 134-142. 